was nothing else left for it to do. It is almost needless to add that, before I could focus and insert a plate, my Navajo baby was out of range. And, fearing that its angered mother might appear at any point, at the cry of alarm of her child, I immediately forsook the ground.

$\mathrm{My}$ object in making a record of such an interesting case as this is to simply draw attention to the fact that the native instincts of these American Indians are exhibited in their young at a wonderfully tender age; and in this particular they differ vastly from our own children at a corresponding time of life, and reared, as they have been for ages, in a civilised environment.

Fort Wingate, New Mexico, January II R. W. SHUFELDT

\section{LONG-LOST REEFS}

A

REMARKABLE instance of the manner in which small reefs in the ocean may elude search has recently been brought to light, and may be of interest to some readers of NATURE.

In June I768 M. de Bougainville, in the frigate $L a$ Boudeuse, having left Espiritu Santo, in the New
Hebrides, was sailing west over the Coral Sea, soutb of New Guinea, near the parallel of $15^{\circ} \mathrm{S}$. At midnight of the $4^{\text {th }}$ he sighted a sand-bank, and waited till daylight to examine it, when it proved to be a very small patch of sand only just out of water, with apparently no reef around it. This he called Bâture de Diane.

Resuming his course west, he, on the 6 th, having run by his reckoning $\mathbf{1} 37$ miles from the sand-bank, sighted a reef on which the sea broke heavily, and closing it, at noon obtained its position. After a zig zag course of five hours, another reef was seen ahead, and as this might be but the prelude to more, the project of exploring further westward was given up, and La boudeuse steered northward, making New Guinea at a bay to which the name of Cul de Sac de l'Orangerie was given. Bougainville thus lost the honour of discovering the eastern coast of Australia, which the celebrated Cook explored two years later. On the last reefs seen no name was bestowed, but they have always been known as the Bougainville Reefs.

Time passed, but these dangers were not again seen.

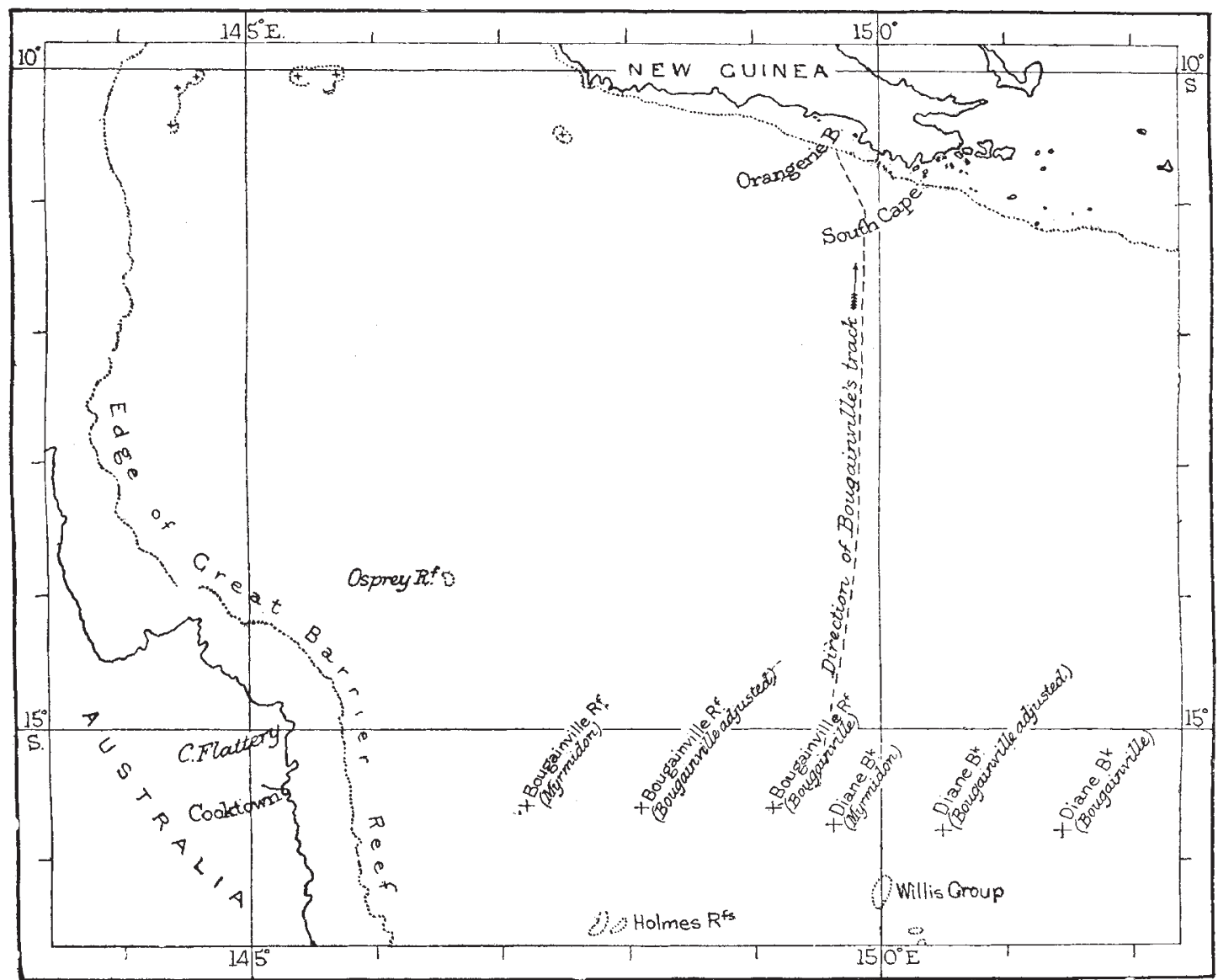

The subject of their existence was much discussed, and on the longitude of Espiritu Santo being revised, it was recognised that $M$. de Bougainville's discoveries should be also moved to the westward about sixty miles-the amount of error in longitude of Espiritu Santo in his time. The Diane was therefore placed in longitude $150^{\circ} 28^{\prime} \mathrm{E}$., and the reefs in $148^{\circ} 6^{\prime}$. In this position they were searched for by Capt. Denham in H.M.S. Herald, who spent fifteen days in traversing in every direction an area of forty miles radius round each danger, but without success. As a result of this search, seeing that Bougainville's description was so circumstantial that the existence of the dangers could scarcely be doubted, they were removed back to their original positions on the charts. These positions, though manifestly too near to Espiritu Santo, agreed better with the land-fall made in New Guinea by La Boudeuse after leaving the last reef, as it seemed impossible that the bay generally supposed to be the Cul de Sac de l'Orangerie could have been reached on the course steered by M. de Bougainville from any position westward of longitude $149^{\circ} 8^{\prime}$ E., Bougainville's own position of the reef.

Many ships passed in fear and trembling over the long line in which it was thought these dange:s might yet 
exist, and the records are full of remarks as to their nonexistence, especially with regard to the Diane, which lay near the main track to Torres Strait from Sydney. They were, however, retained on the charts, with notations as to the doubt in their positions.

At length, in 1884 , two reports were made by small trading-vessels from Queensland to New Guinea, one of a small bank in lat. $15^{\circ} 41^{\prime}$, and long. $149^{\circ} 43^{\prime}$, the other of a submerged reef in lat. $15^{\circ} 28^{\prime}$, long. $147^{\circ} 6^{\prime}$. It was at once observed that the latitudes of these, and their distance apart, agreed with those of Bougainville's discoveries, though they were far to the westward, and it seemed as if the long-lost reefs were at length again found, since it was not at all improbable that the westerly current had caused the reckoning in longitude, uncorrected by chronometers, to be over-run by $L a$ Boudeuse. Capt. Denham's searches, minute and painstaking, and apparently sufficiently extended as they had been, just fell short of the positions of these new reports, the limit of his examinations passing within ten miles of both of them.

One link, however, was missing to insure certainty in the identification, viz. the second reef of Bougainville.

During the past year H.M.S. Myrmidon has been scouring the Coral Sea, and in the course of her cruise made this one object of search. It was, however, unavailing ; clear sea was alone seen in the direction of the second reef. But her description both of sand-bank and reef reported in 1884 tallied precisely with Bougainville's detailed accounts. More accurate observations, moreover, showed that the latitudes were in each case almost exactly identical with his, and that the distances apart, as before stated, agreed.

But what of the reef still missing?

A closer examination of Bougainville's journal revealed that the second reef was sighted from aloft at 5.30 p.m., at an estimated distance of five miles. The sun set at 5.35 , behind the reef; twilight is short in those latitudes, and it seems improbable that La Boudeuse could have been near enough to see the reef clearly before night closed in. It is therelore believed that the delusive appearance of reflection misled the voyagers, and that Bougainville, so accurate in his other reports, was in this instance mistaken.

A further difficulty remains. How could La Boudeuse steering the course reported have made the land Ioo miles to windward of her direct track? Here, again, the explanation seems to be that later voyagers re-bestowed the name of Orangerie on that one of the numerous bays on the New Guinea coast which corresponded to Bougainville's longitude. These are assumptions; but the other evidence is so complete that it is believed that the mystery of I 20 years is cleared up, and that the dangers which have so long been a source of anxiety to the navigator have at length found their true places on the charts.

The three positions these reefs have occupied are as follows :-

$$
\begin{aligned}
& \begin{array}{ccc}
\text { By } & \text { corrected } & \text { By } \\
\text { Bougainville } & \text { for the position of } & \text { Myrmido }
\end{array} \\
& \text { S. E. Espiritu Santo } \quad \text { S. E. }
\end{aligned}
$$

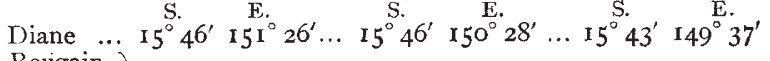

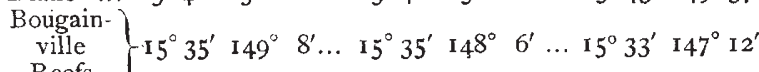

$$
\begin{aligned}
& \text { Reefs } \int \begin{array}{l}
1535^{\circ} 149^{\circ} \text { W. J. L. WHARTON } \\
\text { Whar }
\end{array}
\end{aligned}
$$

\section{THE CROCUS ${ }^{1}$}

M ANY splendidly printed and illustrated monographs $\mathrm{N}$ of special genera of flowering plants have been published, but few surpass in merit or interest Mr. Maw's " "A Monograph of the Genus Crocus." By George Maw, F.L.S. \&c. With an Appendix on the etymology of the words "Crocus" and "Saffron," by C. C. Lacaita, M.A., M.P., F.I.S. (London: Dulau and Co., r886.) monograph of the species of the genus Crocus. This work, the author tells us, has pleasantly occupied his spare hours for the last eight years. In collecting the material for it, he has travelled far and wide over the crocus region; he bas enlisted the services of a whole host of friends, who, on the borders of the Mediterranean, of the great Basin of the Black Sea, and along the shores of the Caspian, have collected the species peculiar to these localities, and forwarded them for culture and description to Mr. Maw. Perhaps never before has a monograph been written so entirely from the study of living plants. At the same time, no information that was to be gleaned from the dried specimens in herbaria has been neglected.

The monograph opens with a chapter on the life-history and physiology of the forms belonging to the genus. As the minute structure of the various parts of the plants has not been made a special study by the author, this portion of the subject leaves a good deal to be done by future workers. The strange phenomenon of dissepiments on the pollen-tube is figured as existing, on the authority of Prof. Martin Duncan. In the chapter on classification and sequence, we find that the author adopts the division of the species indicated by Dean Herbert, into those with, and those without, a basal spathe. These larger divisions are, again, subdivided into sections, characterised by the form assumed by the bundle tissue or the corm tissues, and these, again, into groups arranged according to the period of flowering. The third chapter is a most interesting one, on the geographical distribution of the species. Confined to the Old World, the species of crocus are therein only to be met with in the northern hemisphere, where they reach a northern limit at about $50^{\circ} \mathrm{N}$. latitude. Westwards, they reach their limit at the coast of Portugal ; southwards, the limit extends to Morocco, though no species appear to be endemic to Africa, and none have been founa in the region between Tetuan and the Nile Delta. In Asia, on the borders of Syria, Crocus hyemalis has the most southern range of all the species. The eastern limit of the species is at present uncertain, for it seems pretty certain that one or more species have been found in Afghan Turkestan. Of the sixty-nine known species, thirty occur in $40^{\circ} \mathrm{N}$. latitude, which is far in advance of any other district as a line of growth, but the metropolis of the grenus is a district including Greece, the Greek Archipelago, and Asia Minor, for in these regions it forms a more important feature in the flora than in the outlying countries to which it extends. The genus is also remarkable for the wide range in altitude of the majority of the species, those that are essentially alpine or lowland being comparatively few in number; and Mr. Maw does not know of a single species which is not perfectly hardy, that is to say, capable of enduring any of the extremes of cold or heat to be met with in our climate. There do not appear to be distinct areas for the spring and autumn flowering forms, and Mr. Maw has been unable to detect any instances of wild hybrid forms, notwithstanding the close relationship of some of the species, and the fact that their areas of distribution constantly overlap.

In a fourth chapter the history and literature of the genus are treated of. Two centuries before the days of Linnæus the crocus was known in England as a garden plant, and in Gerarde's "Herball " (1597) eleven forms are figured and described. Most of the famous pre-Linnean writers on plants have added to our knowledge of the species, such as Parkinson in his "Paradisus" (I629), and Ewart in his "Florilegium" (I6I2); but Linnæus contented himself with making but two species, one $C$. vernus, and the other $C$. (Bulbocodium) bulbocodium. The first important attempt to classify the genus was made by A. H. Haworth in 1809 , followed by Goldbach's monograph in 1817 , Gay's in 1827 , and Sabine's in 1830 . Dean Herbert in 1847 and Baker in 1873 added much to our scientific knowledge of the group, and now in this beautiful monograph 